\title{
Jurnalisme Sains dan Sistem Peringatan Dini Bencana di Indonesia
}

\author{
Rana Akbari Fitriawan ${ }^{1}$ \\ Program Studi Ilmu Komunikasi, Fakultas Komunikasi dan Bisnis, Universitas \\ Telkom
}

\begin{abstract}
Indonesia is rich in magnificent natural resources, however also is rife with natural disasters. Government recorded, during JanuaryNovember 2014 natural disasters had happened more than 161 times, ranging from earthquakes, mountain eruptions, tsunami, tornadoes, landslides, to floods. These did not include forest fires which occurred in almost all major islands in Indonesia. This disaster prone condition requires all parties to participate in overcoming it, including mass media. This is in line with the functions of media which are overseeing the interests of society, warning of the danger such as natural disasters, epidemics, war, and so on. This research employs content analysis to examine how science journalism - a genre of journalism that uses a scientific approach- supports disaster early warning system. The results show that journalism plays an important role in supporting disaster early warning system in Indonesia by practicing science journalism. The most obvious role is presenting scientific report in popular language. Hence, the disaster news is not only compiling hard facts, but also scientific information in order to help the audience making the right decision when facing disaster.
\end{abstract}

Keywords: disasters, media, science journalism

\begin{abstract}
Abstrak
Memiliki daratan dan lautan yang luas, Indonesia tidak hanya kaya dengan pesona alam yang menakjubkan, tapi sekaligus menyimpan ancaman bencana yang menakutkan. Pemerintah mencatat, antara Januari-November 2014 sudah terjadi bencana alam lebih dari 161 kali seperti gempa bumi, letusan gunung berapi, tsunami, angin puting beliung, tanah longsor, dan banjir. Ini belum termasuk kebakaran hutan yang terjadi di hampir seluruh pulau besar di Indonesia. Kondisi ini membutuhkan peran semua pihak untuk mengatasinya, termasuk media
\end{abstract}

\footnotetext{
1 Korespondensi Penulis :

Rana Akbari Fitriawan, Program Studi Ilmu Komunikasi, Fakultas Komunikasi dan Bisnis, Universitas Telkom, Jalan Telekomunikasi No. 1 Terusan Buah Batu Bandung, Jawa Barat, Indonesia

ranaakbar@telkomuniversity.ac.id
} 
massa. Ini seiring dengan fungsi nyata media antara lain mengawasi kepentingan masyarakat dengan memberi peringatan tentang bahaya yang mengancam seperti bencana alam, wabah penyakit, perang, dan sebagainya. Menggunakan kajian kepustakaan serta analisis terhadap konten jurnalisme sains di beberapa media, tulisan singkat ini mencoba melihat bagaimana jurnalisme sains, sebuah genre jurnalisme yang menggunakan pendekatan sains, mengambil peran dalam mendukung sistem peringatan dini bencana. Hasil penelitian menunjukkan bahwa jurnalisme dapat mengambil peran penting dalam mendukung sistem peringatan dini bencana di Indonesia dengan menerapkan metode jurnalisme sains. Peran yang paling nyata dengan menyajikan pelaporan ilmiah yang diramu dengan bahasa populer. Dengan begitu, pemberitaan tentang bencana tidak hanya menyajikan peristiwa, namun pelaporan ilmiah, sehingga khalayak dapat menjadikannya sebagai pedoman saat mengambil keputusan yang tepat menghadapi bencana.

Kata kunci: bencana, media, jurnalisme sains

\section{Pendahuluan}

Banyak hal menarik yang berkecamuk di benak Dr. Brian F. Atwater, pakar dari Badan Survei Geologi AS (USGS) selepas gelombang hebat tsunami menghempas Aceh dan beberapa negara Asia lain yang terjadi pada 25 Desember 2004. Bersama rekannya dari Indonesia, Dr. Eko Yulianto, yang merupakan peneliti pada Lembaga Ilmu Pengetahuan Indonesia (LIPI), Atwater melakukan penelitian untuk mengetahui bencana yang meluluhlantakkan sebagian besar Aceh itu.

Para peneliti ini menerapkan sejumlah metode antara lain dengan menggali tanah di beberapa pantai di Indonesia yang pernah dihempas oleh gempa dan tsunami seperti di Meulaboh, Nanggroe Aceh Darussalam (NAD) dan tebing Sungai Cikembulan, Pangandaran, Jawa Barat. Dari penggalian itu, mereka dapat melihat lapisan-lapisan tanah yang warna dan teksturnya berbeda satu sama lain. Mereka menyimpulkan, berdasar endapan paleotsunami, dapat dilihat bahwa pernah terjadi tsunami raksasa (giant tsunami) di Aceh sekitar 600 tahun silam. Ini membantah anggapan atau keyakinan bahwa tsunami yang melanda Aceh pada 2004 silam diyakini merupakan tsunami terbesar yang pernah melanda kawasan tersebut.

Menurut Eko dalam sebuah presentasi di Pusat Studi Bencana Universitas Gajah Mada (PSB UGM) 2011 silam, data tersebut menepis anggapan bahwa sebelumnya di Aceh tidak pernah terjadi gempa bumi yang dahsyat di atas 9,0 skala Richter. Tsunami pada 2004 yang meluluhlantahkan Aceh merupakan bukti bahwa gempa bumi dan tsunami berskala besar bisa terjadi di mana saja. Sayangnya, temuan ini diperoleh setelah terjadi gempa di Aceh. Jika ditemukan lebih cepat, jumlah korban gempa dan tsunami bisa diminimalisir (ugm.ac.id).

Masih pada kesempatan yang sama, Eko mengatakan telah melakukan penelitian serupa di tempat lain seperti tebing Sungai Cikembulan, Pangandaran, Jawa Barat setelah Tsunami menerjang pantai selatan itu pada 2006. Para peneliti menemukan ada empat lapisan pasir yang menjadi bukti awal di kawasan tersebut 
pernah terjadi beberapa kali tsunami. Salah satunya berupa lapisan pasir tebal yang diendapkan di atas lumpur mangrove dan ditutupi endapan banjir. Pada lapisan pasir tersebut terdapat cangkang foraminifera. Di atas lapisan itu terdapat beberapa lapisan yang memiliki ketebalan sekitar 1-3 cm, salah satunya merupakan bekas tsunami Pangandaran 2006 lalu. Ini menunjukkan kurang lebih 400 tahun yang lalu, di wilayah ini diperkirakan pernah terjadi tsunami yang skalanya jauh lebih besar dibanding tsunami 2006 kemarin (Kompas, 2011).

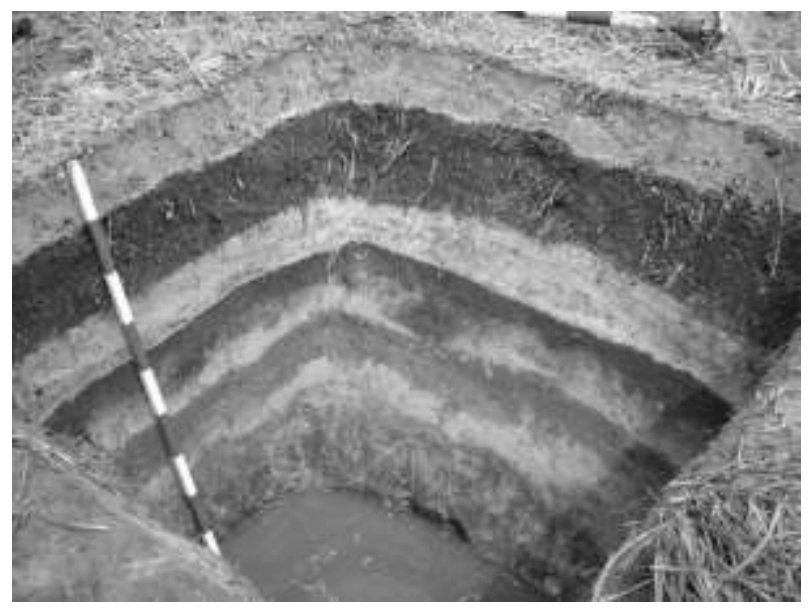

Gambar 1. Lubang Lapisan Tsunami Sumber: lipi.go.id

Temuan ini memperlihatkan bahwa tsunami sudah pernah menerjang beberapa tempat di Indonesia dan meninggalkan korban jiwa dan kerusakan materi yang sangat besar. Jika apa yang disimpulkan para ahli itu benar adanya, berarti bencana gempa yang disusul dengan tsunami besar dapat terjadi di mana dan kapan saja di seluruh Indonesia. Pertanyaannya, apa yang harus dilakukan oleh rakyat Indonesia dalam mengantisipasinya? Sudahkah Indonesia memiliki sistem peringatan dini (early warning system) yang efektif dan aplikatif yang dengan begitu masyarakat dapat mengantispasi kehadiran tsunami ini?

Ini sejalan dengan pertanyaan Atwater: jika bencana besar tsunami pernah terjadi di sejumlah kawasan di Indonesia dan kemungkinan besar bencana serupa akan terjadi lagi pada beberapa ratus tahun mendatang, siapakah yang dapat memberitahukan kepada masyarakat Indonesia sehingga mereka dapat mempersiapkan diri atau mengantisipasi terjangan air bah dari laut ini? Sistem peringatan sejak dini (early warning system) sangat diperlukan agar masyarakat dapat lebih siap sistem menghadapi bencana ini dan dapat meminimalisasi jumlah korban jiwa dan kerugian harta benda. Pertanyaan dari ilmuwan ini terasa menjadi sangat penting mengingat Indonesia adalah negara besar yang mempunyai kekayaan alam tak terhitung jumlahnya. Data Badan Pusat Statistik dan Kementerian Kelautan menyebutkan luas daratan Indonesia tidak kurang dari 1,91 juta kilometer persegi dengan luas lautan luas lautan mencapai lebih dari 3,5 juta kilometer persegi. Di dalam 
dan di atas tanahnya terhampar kekayaan yang tak ternilai.

Namun, di balik kekayaan alam yang menakjubkan itu, Indonesia juga menyimpan potensi bencana yang sangat besar. Rekapitulasi Data Kejadian Bencana antara Januari-November 2014 dari Direktorat Perlindungan Sosial Korban Bencana Alam mencatat sudah terjadi 161 bencana di Indonesia mulai dari bencana alam seperti gempa bumi, letusan gunung berapi, tsunami, dan angin puting beliung hingga bencana yang disebabkan oleh ulah manusia seperti tanah longsor atau banjir (Arif, 2010). Tentunya ini belum termasuk bencana asap yang saat ini terjadi di sebagian hutan di Pulau Sumatera, Kalimantan, Papua, dan Jawa yang sebagian asapnya mencemari negara tetangga.

Data yang dikumpulkan penulis memperlihatkan bencana di Indonesia, baik berupa bencana alam maupun bencana yang disebabkan keterlibatan manusia di dalamnya, terjadi sudah sekian lama, berulang, dan mengakibatkan kerugian yang sangat besar. Tsunami, misalnya, merupakan bencana alam yang "jarang" terjadi dibandingkan dengan bencana alam lain, namun menimbulkan korban tak terkira. Catatan Direktorat Vulkanologi dan Mitigasi Bencana Geologi Departemen Energi dan Sumber Daya Mineral menunjukkan bahwa ada 28 wilayah di Indonesia yang dinyatakan rawan gempa dan tsunami. Selama kurun waktu 200 tahun (1801-2003) tak kurang 161 tsunami terjadi di Nusantara. Sekitar 73 persen tsunami terjadi di bagian timur Indonesia di wilayah yang terbentang dari Selat Makassar ke arah timur (Tabel 1, Arif, 2010:28).

Bencana lain yang tidak kalah serius misalnya kebakaran hutan yang terjadi hampir setiap tahun. Data Kementerian Lingkungan Hidup dan Kehutanan menyebutkan kebakaran lahan dan hutan tahun 2015 lalu telah mencapai sekitar 1,7 juta hektar. Ini merupakan angka tertinggi sejak tahun 1997. Akibat kebakaran hutan dan lahan, negara diperkirakan mengalami kerugian hingga triliunan rupiah. (Harian Kompas 29 Oktober 2015:2). Sumber lain menaksir 2,6 juta hektar hutan, lahan gambut, dan lahan lain dilalap amukan api. Angka itu sama dengan 4,5 kali luas Bali.

Memang, dalam kebakaran hebat sebelumnya (1997/1998) luas lahan yang terbakar lebih-kurang sama dengan tahun ini. Tapi dampaknya sekarang jauh lebih parah. El Nino yang menyertai kebakaran membuat musim hujan terlambat tiba, sehingga api kian lama menyala. Lagi pula ketahanan ekosistem saat ini lebih rentan karena banyak lahan telah terdegradasi menjadi hutan sawit. Akibatnya jutaan penduduk juga semakin lama terpapar asap yang membahayakan kesehatan itu (Tempo, 28 Desember 2015-3 Januari 2016: 42).

Kerugian yang ditimbulkan bukan hanya pada luasnya lahan yang terbakar tapi juga berupa penyakit yang diderita warga serta timbulnya dampak ekonomi-sosial. Data menyebutkan, paling tidak 14 ribu orang di Sumatera Selatan dan Riau terserang infeksi saluran pernafasan akut, 3.000 orang mengalami iritasi mata dan kulit, 1.200 menderita asma, dan 500 mengidap pneumonia. Selain itu, tidak kurang dari 5 juta siswa kehilangan waktu belajar cukup lama. 
Tabel 1. Data Bencana Tsunami yang Pernah Terjadi di Indonesia

\begin{tabular}{|l|l|l|l|}
\hline No & \multicolumn{1}{|c|}{ Tempat } & \multicolumn{1}{c|}{ Waktu } & \multicolumn{1}{c|}{ Keterangan } \\
\hline 1 & Halmahera & 5 April 1969 & \multicolumn{1}{|c|}{} \\
\hline 2 & Laut Banda & 17 Februari 1674 & $\begin{array}{l}\text { Tinggi gelombang } \\
\text { diperkirakan mencapai 80 } \\
\text { meter dengan korban sekitar } \\
3.000 \text { orang }\end{array}$ \\
\hline 3 & $\begin{array}{l}\text { Lombok Timur (Nusa } \\
\text { Tenggara Barat) }\end{array}$ & 19 Agustus 1977 & \\
\hline 4 & $\begin{array}{l}\text { Pantai Selatan Pulau } \\
\text { Lomblen Kabupaten Flores } \\
\text { Timur Nusa Tenggara Timur }\end{array}$ & 18 Juli 1979 & 12 Desember \\
\hline 5 & $\begin{array}{l}\text { Flores (Nusa Tenggara } \\
\text { Timur) }\end{array}$ & $\begin{array}{l}\text { Gempa 7,5 skala Richter, } \\
\text { korban tewas 2.080 jiwa }\end{array}$ \\
\hline 6 & Banyuwangi (Jawa Timur) & 3 Juni 1994 & Korban tewas 377 orang \\
\hline 7 & Tolitoli (Sulawesi Tengah) & 1 Januari 1996 & Korban tewas 9 orang \\
\hline 8 & Biak Numfor (Papua) & 17 Februari 1996 & Korban tewas 166 orang \\
\hline 9 & Maluku Utara & $\begin{array}{l}\text { 29 November } \\
1998\end{array}$ & Korban tewas 30 jiwa \\
\hline 10 & Banggai & Tahun 2000 & Korban tewas 50 orang \\
\hline 11 & Aceh dan Nias & $\begin{array}{l}\text { 26 Desember } \\
\text { 2004 }\end{array}$ & Korban tewas 150.000 orang \\
\hline
\end{tabular}

diolah dari : Arif (2010:28)

Sektor ekonomi mengalami kerugian yang tidak kalah serius antara lain pada sektor transportasi, pertanian, industri, dan logistik. Kabut asap menyebabkan ribuan penerbangan dibatalkan sehingga Maskapai Garuda Indonesia saja hingga Oktober 2015 sudah batal membumbungkan pesawat hingga 1.600 kali. Ketua Asosiasi Logistik Indonesia, Zaldy Masita, memperkirakan kerugian perusahaan-perusahaan logistik mencapai Rp50 Miliar karena adanya tambahan biaya angkut klaim konsumen dan bertambahnya biaya Inventory. Data Badan Nasional Penanggulangan Bencana (BNPB) menyebutkan total kerugian ekonomi akibat kebakaran 2015 lebih kurang sama dengan tahun sebelumnya yakni Rp50 Triliun. Namun Herry Purnomo, peneliti pada Center for International Forestry Research memperkirakan dampak ekonomi jauh lebih besar yakni Rp200 Triliun (Tempo, 28 Desember 2015-3 Januari 2016:43)

Oleh karena itu Menteri Lingkungan Hidup dan Kehutanan Siti Nurbaya Bakar menilai kasus kebakaran hutan dan lahan termasuk extraordinary crime. Kebakaran hutan ini telah merugikan negara dan mengancam keselamatan masyarakat dan lingkungan hidup. Satu hal yang tidak kalah penting, akar masalahnya tidak pernah dituntaskan. Tanpa menyentuh faktor sosial ekonomi masyarakat, penegakan hukum kuat, praktik bisnis perkebunan ramah lingkungan, revisi regulasi yang keliru, dan pencegahan kebakaran secara sistematis, kebakaran hutan dan lahan yang menimbulkan kabut asap pekat akan menjadi lebih parah (Harian Kompas, Kamis, 29 Oktober 2015:1)

Sementara itu, pada tahun 2015 sendiri BNPB mencatat jumlah bencana tidak kurang dari 1.582 kejadian dengan jumlah korban tewas 240 orang, dan jumlah 
pengungsi 1,18 juta orang. Sedangkan jumlah rumah rusak berat 4.977 unit, jumlah rumah rusak sedang 3.461 unit, jumlah rumah rusak ringan 15.927 unit, dan jumlah fasilitas umum rusak 484 unit. Tercatat pula lima Provinsi terbanyak kejadian bencana yakni Jawa Tengah (363 kejadian), Jawa Timur (291 kejadian), Jawa Barat (209 kejadian), Sumatra Barat (93 kejadian), dan Aceh (85 kejadian) (Republika Online, 2015).

Menimbang begitu banyak korban jiwa serta besarnya dampak ekonomi-sosial yang ditimbulkan, maka perlu kiranya Indonesia memiliki sistem peringatan dini (early warning system) yang komprehensif. Titik soalnya, sistem peringatan dini yang ada selama ini masih dipahami sebagai penambahan infrastruktur semata. Sekadar contoh, pemerintah di bawah kepemimpinan Joko Widodo menyiapkan anggaran sebesar Rp150 Miliar untuk penanganan banjir dan tanah longsor yang sering terjadi saat musim hujan. Dana tersebut salah satunya dapat digunakan pemerintah daerah untuk melakukan kegiatan tanggap darurat seperti mendirikan posko, mobilisasi dan pemberdayaan manusia untuk melindungi warga yang terdampak bencana banjir dan longsor terutama bagi 279 daerah di Indonesia yang teridentifikasi rawan banjir dan longsor (Kompas Online).

Meneguhkan perannya melalui media massa, jurnalisme dapat mengambil peran penting dalam mendukung sistem peringatan dini bencana di Indonesia, yaitu dengan menerapkan metode jurnalisme sains sebagai salah satu alternatif untuk menjembatani para ilmuwan yang melakukan kajian ilmiah, dengan publik terutama warga yang tinggal di daerah rawan bencana. Untuk itu penelitian ini dirumuskan lebih lanjut menjadi: "Peran dan fungsi apakah yang dapat dilakukan jurnalisme dalam dalam sosialisasi bencana terhadap masyarakat, serta apa dan bagaimana sajakah bentuk-bentuk jurnalisme sains yang dapat dikembangkan dalam sosialisasi bencana terhadap masyarakat?"

\section{Metode}

Makalah ini merupakan hasil penelitian kepustakaan dengan pendekatan kualitatif dipadukan dengan analisis isi terhadap beberapa contoh karya jurnalisme sains, terkait pengembangan jurnalisme sains dan sistem peringatan dini bencana di Indonesia. Sumber data yang digunakan mencakup berbagai tinjauan kepustakaan dari berbagai media massa tentang perlunya sistem peringatan dini bencana pada masyarakat Indonesia, tinjauan teori dan konsep tentang fungsi sosial media massa, serta pengembangan jurnalisme sains di Indonesia yang dilakukan melalui pembahasan terhadap contoh konten jurnalisme sains pada beberapa media di Indonesia.

\section{Kajian Pustaka}

\section{Media Massa dan Fungsi Sosial}

Sudah sejak lama para teoritikus klasik percaya bahwa media massa memiliki fungsi paling tidak memberi informasi, mendidik, menghibur, dan kontrol sosial. Dalam perjalanannya, sejumlah ahli mengembangkan lagi fungsi-fungsi media ini misalnya 
Laswell dan Wright dalam Serverin dan Tankard (1992) yang menyatakan bahwa fungsi nyata (manifest function) dari media antara lain: pengawasan untuk kepentingan masyarakat. Media massa dapat memberi peringatan tentang bahaya yang mengancam seperti bencana alam, wabah penyakit, perang, dan sebagainya. Dengan peringatan ini masyarakat dapat mencegah kerusakan dan kerugian, waspada terhadap bahaya yang sewaktu-waktu dapat terjadi; penghubung suatu berita atau isi media dapat berfungsi meningkatkan mobilisasi dan mengurangi ancaman terhadap stabilitas sosial mengurangi kepanikan masyarakat. Adapun untuk kepentingan individu media massa dapat memberi efisiensi mengasimilasi berita mengurangi stimulasi yang berlebih mengurangi kecemasan dan sikap apatis; transmisi budaya antar generasi dengan mewariskan nilai-nilai sosial dan budaya dari generasi ke generasi; entertainment atau hiburan sebagai tindakan komunikatif yang terutama dimaksudkan untuk menyenangkan pikiran dan hati dengan tidak mengindahkan pemilihan instrumental musik atau tidak (Unde, 2014:84).

Sejalan dengan itu, McQuail (1996) juga menjelaskan mengenai fungsi media yaitu: fungsi informasi yaitu media menyediakan informasi tentang peristiwa dan kondisi dalam masyarakat, menunjukkan hubungan dengan pihak kekuasaan, memudahkan inovasi, adaptasi, dan kemajuan; fungsi korelasi yaitu menjelaskan menafsirkan mengomentari makna peristiwa dan informasi menunjang otoritas dan norma-norma yang mapan melakukan sosialisasi mengkoordinasi berbagai kegiatan membentuk kesepakatan dan menentukan urutan prioritas; fungsi kesinambungan yaitu mengekspresi budaya dominan dan mengakui keberadaan budaya khusus serta mengembangkan budaya baru meningkatkan dan melestarikan nilai-nilai lama yang tetap relevan; fungsi mobilisasi yaitu mengkampanyekan tujuan masyarakat dalam bidang politik, pembangunan ekonomi, dan juga agama (Unde, 2014:85).

Di Indonesia, ahli komunikasi Astrid Susanto juga memberi perhatian tentang fungsi sosial dari media massa yaitu: sebagai sarana komunikasi antar kelompok; memberitahukan sebelum ada bahaya; memberi harga diri kebanggaan; memberi status (Unde, 2014:86). Maka dari beberapa pernyataan di atas, dapat dilihat bahwa fungsi yang mesti ada adalah informatif dan pengawasan. Dalam konteks ini, maka fungsi media adalah menginformasikan tentang ancaman bencana alam serta mengingatkan masyarakat tentang bahaya yang mengintainya.

Memang tidak dapat dipungkiri bahwa fungsi media massa ini sempat dikritisi oleh akademisi maupun praktisi media karena seringkali hanya menjadi semacam 'lip service'. Kritik yang cukup keras misalnya datang dari Danny Schechter melalui bukunya The Death of Media and The Fight to Save Democracy. Schechter memaparkan di Amerika Serikat, dan kecenderungan yang sama juga terjadi di negaranegara lain di dunia, media sudah dikooptasi oleh segelintir pemiliknya yang membelokkan orientasinya sudah bukan untuk kepentingan publik melainkan sematamata bisnis dan politik.

Schechter juga menulis bahwa dia tidak sendirian dalam 'kegeraman' terhadap penyimpangan fungsi media massa ini. Sejarawan media Robert McChesney, penulis 
Michael Crichton, dan penulis novel Bruce Sterling sudah lama mendeteksi kematian media ini. Media saat ini, menurut Schechter, adalah tempat berdagang. Mereka lebih banyak menjual dibandingkan mengungkapkan sesuatu. Lewat diskusi kelompok terfokus (focus group) dan teknik lain, penonton dipikat dan dipertahankan menggunakan humor, narasi dramatis dan berita yang dibesar-besarkan. Semuanya sangat kuat dan menggoda serta dirancang dengan teliti. Media massa kini paham bahwa penonton ingin dan butuh untuk dialihkan perhatiannya dari hidup yang sarat masalah dan kelelahan akibat pekerjaan (2007:14).

Meski demikian, tentu masih ada media yang mau dan mampu menjalankan fungsi sosialnya di tengah-tengah tekanan ekonomi politik itu. Sterling sendiri mengungkapkan, satu hal yang paling penting adalah relasi personal seperti yang dibangun dengan begitu banyak dunia media, bagaimana memanfaatkan media dan bagaimana memastikan agar tidak diperalat oleh media (Schechter, 2007:17). Dengan demikian tidak berlebihan kiranya jika penulis berpendapat bahwa di tengah-tengah bencana yang datang silih berganti, masyarakat Indonesia masih menggantungkan harapan terhadap media agar tidak hanya memberitakan fakta, tapi lebih jauh dapat berpartisipasi mencegah bencana berikutnya.

Media massa yang dimaksud dalam tulisan ini merujuk pada sebutan media massa, media pers dan media jurnalisme, yang keseluruhannya dimaksudkan untuk menunjuk media komunikasi massa yang mengutamakan informasi faktual, baik media cetak (suratkabar dan majalah) maupun elektronik (radio dan televisi) serta media dalam jaringan (online - penulis) yang dikenal sebagai media berita. Media semacam ini merupakan hasil kerja profesi jurnalisme (Siregar, 2000:171).

\section{Jurnalisme dan Pendekatan Sains}

Jurnalistik atau jurnalisme berasal dari kata journal, artinya catatan harian, atau catatan mengenai kejadian sehari-hari. MacDougal dalam Kusumaningrat menyebutkan bahwa jurnalisme adalah kegiatan menghimpun berita, mencari fakta, dan melaporkan peristiwa. Jurnalisme sangat penting di mana pun dan kapan pun. Jurnalisme sangat diperlukan dalam suatu negara demokratis. Tak perduli apa pun perubahan-perubahan yang terjadi di masa depan - baik sosial, ekonomi, politik maupun yang lain-lainnya (2005:15). Sejak ada acta diurna pada zaman Kaisar Romawi Julius Caesar yang kemudian dipercaya sebagai cikal bakal kelahiran jurnalisme, perkembangan jurnalisme pada tataran praktis terus melalui berbagai tahapan terutama saat diciptakannya mesin cetak oleh Johann Gutenberg pada abad 14 (Harrower, 2010:8).

Pada tataran ilmu pengetahuan, jurnalisme pun terus mengembangkan dirinya. Perubahan besar dalam bidang teknologi khususnya information and communication technology (ICT) mendorong jurnalisme pun berubah cepat. Sementara di sisi lain, jumlah audiens media massa yang mengecap pendidikan semakin bertambah jumlahnya. Mereka menuntut kualitas hidup yang lebih baik seperti ketersediaan fasilitas untuk hidup aman dan nyaman, akses kesehatan dan pendidikan yang layak, dan sebagainya. Khusus di Indonesia, perubahan cepat juga didorong runtuhnya rezim 
Orde Baru yang digantikan oleh kekuatan rakyat yang menghendaki adanya reformasi di segala bidang.

Pada masa inilah salah satu sajian yang ditawarkan oleh media massa adalah informasi menyeluruh yang "diproduksi" dengan menggunakan jurnalisme sains. Science berasal dari kata Latin scientia yang berarti pengetahuan (Werner dan Fenton dalam Indiyanto (2012:8). Maka jurnalisme sains dapat dikatakan sebagai metode yang dipilih untuk menyampaikan karya jurnalisme dengan pendekatan ilmiah.

Metode ini biasanya melibatkan interaksi antara ilmuwan, jurnalis, dan masyarakat. Menurut Ashadi Siregar, dua profesi yakni junalis dan peneliti, pada dasarnya memiliki kesamaan episteme, yaitu obyektivitas. Bahwa objektivitas selamanya memiliki dua sisi mata koin tak terpisah: kebenaran (truth) pada obyek faktual dan netralitas pada diri pelaku. Artinya di satu sisi menghargai kebenaran pada obyek dan menekan kepentingan subyektif diri pada sisi lainnya. (Siregar, Kompas 11 Agustus 2015)

Sebagai sebuah metode pelaporan, jurnalisme sains sebenarnya sudah cukup lama dipilih oleh para jurnalis. Sekadar contoh, Emma Reh [Stevenson], lulusan George Washington University yang cukup lama memiliki ketertarikan dalam menulis pelaporan jurnalisme dengan menggunakan pendekatan ilmiah ketika dia bekerja untuk Science Service pada pertengahan 1920-an. Selama hidupnya, perempuan yang pernah menjadi koresponden di beberapa media seperti Mexican News Features dan Christian Science Monitor ini mengawinkan dunia jurnalisme dengan arkeologi dan antropologi (siarchives.si.edu).

\section{Hasil dan Pembahasan}

Di Indonesia, sebagian media massa sudah menerapkan jurnalisme sains dalam pelaporan mereka. Secara teknis, ada media massa yang menggunakan metode ini sebatas untuk rubrik (di media cetak), atau program (media siaran) "Iptek", "Science" atau program lainnya yang membahas tentang ilmu pengetahuan (lihat Gambar 1). Namun ada pula media yang menerapkan jurnalisme sains saat melapor-kan isu politik, sosial, olah raga, hingga lingkungan.

Pada perjalanannya, tuntutan tentang berita yang akurat dan ilmiah ini terus berkembang sehingga mendorong puluhan jurnalis dari berbagai media massa untuk berkumpul dan mendiskusikannya lebih serius. Mereka bersama sejumlah ilmuwan dari berbagai perguruan tinggi, Lembaga Ilmu Pengetahuan Indonesia (LIPI) dan institusi lain untuk pertama kalinya menyelenggarakan Konferensi Jurnalis Sains Indonesia (Indonesian Science Journalists Conference) di Litbang KLHK, Bogor, Jawa Barat, pada tanggal 29-30 Agustus 2015.

Pada konferensi itu antara lain didiskusikan kolaborasi antara jurnalis dengan ilmuwan agar penyampaian berita kepada khalayak tidak semata-mata berita yang "kering" dan "sepintas". Menurut Kepala Pengembangan Produk Digital Majalah TEMPO, Yosep Suprayogi, kolaborasi ini penting mengingat di antara jurnalis dengan ilmuwan seringkali memiliki tujuan yang sama untuk membagi informasi kepada 
masyarakat, tapi kerap menemukan perbedaan bahasa dan cara menyampaikannya.

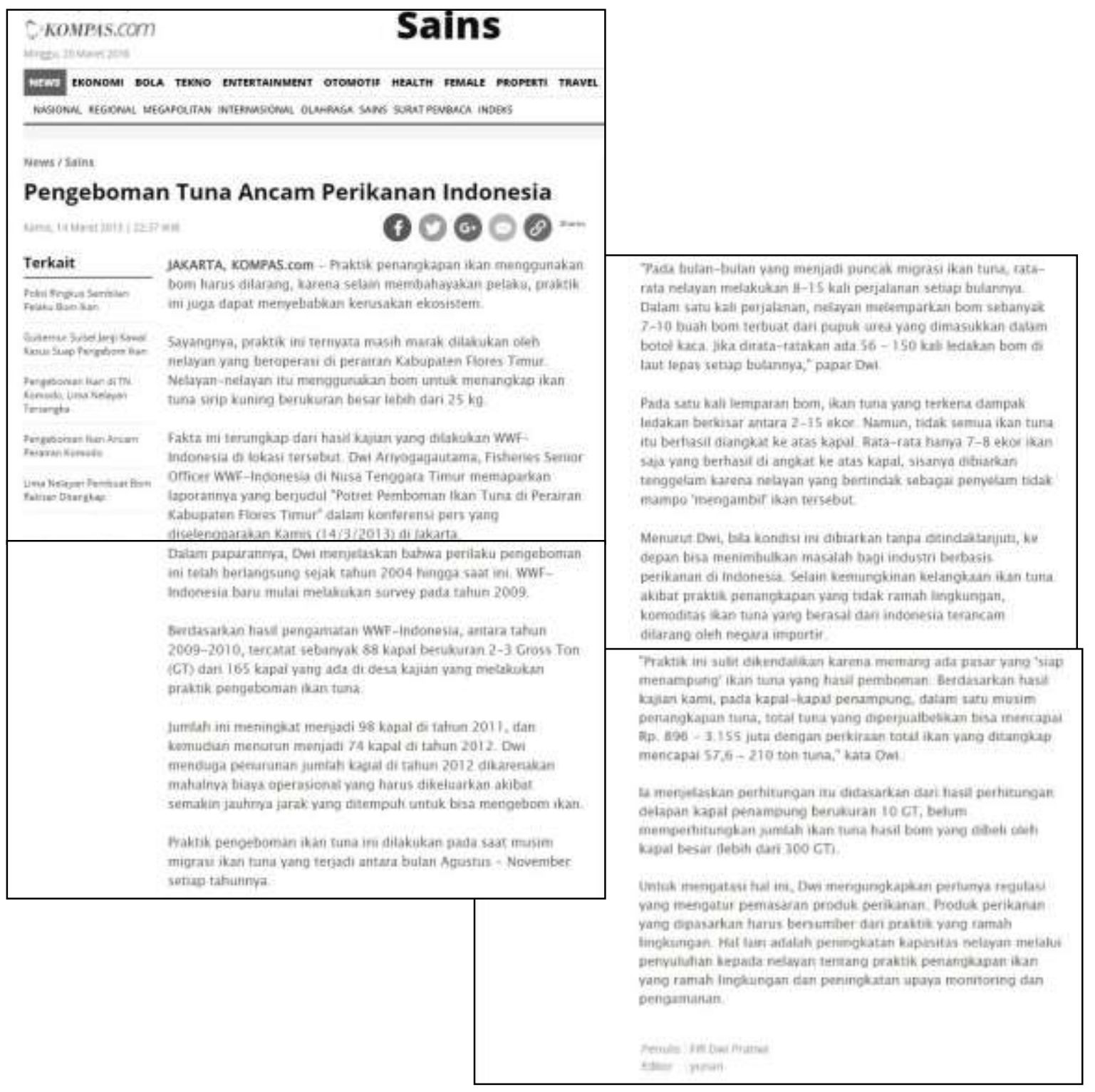

Gambar 2. Contoh Jurnalisme Sains dalam Rubrik "Sains" Sumber: kompas.com, 14 Maret 2013

Perbedaan itu antara lain terlihat pada: 1) tugas jurnalis adalah menyampaikan "apa yang baru"; 2) seorang jurnalis akan mengatakan: "Saya di sana, Anda tidak, jadi biarkan saya menceritakan tentang itu kepada Anda"; 3) ilmuwan menyampaikan "bagaimana dunia bekerja"; dan 4) ilmuwan mengatakan "Saya mengerti sesuatu tentang dunia ini, Anda tidak, jadi biarkan saya menerangkannya untuk Anda." 
Tabel 2.

Perbedaan Jurnalis dengan Ilmuwan ${ }^{2}$

\begin{tabular}{|c|c|}
\hline Jurnalisme mengutamakan: & Sains mengutamakan: \\
\hline - Keringkasan & - Detil \\
\hline - Perkiraan & - Akurasi \\
\hline - Personal & - Impersonal \\
\hline - Bahasa percakapan & - Bahasa teknis \\
\hline - Kecepatan & - Kekekalan \\
\hline - Cerita & - Fakta \\
\hline - Kata & - Angka \\
\hline - Being right now & - Being right \\
\hline
\end{tabular}

Sumber: materi Konferensi Jurnalis Sains Indonesia 2015

Dengan demikian, tujuan dari jurnalisme sains adalah membuat informasi yang sangat detil, spesifik, dan kerap sarat jargon yang dihasilkan ilmuwan ke dalam sebuah bentuk yang dapat dipahami dan disukai mereka yang bukan ilmuwan, namun informasi yang disampaikan tetap akurat. Untuk mencapai tujuan ini, dalam menyusun pelaporannya, jurnalis sains menghindari model defisit informasi komunikasi. Model ini mengasumsikan top-down dan satu arah (one way communications). Sebaliknya, cara berkomunikasi informasi yang dipilih adalah dengan membuka akses dialog yang terbuka antara jurnalis, pemegang pengetahuan, dan masyarakat.

Contoh lain penerapan jurnalisme sains terdapat dalam salah satu pelaporan di Koran Tempo Online edisi 5 Oktober 2015 berjudul "Pasir Miliaran dari Pantai Watu Pecak". Pelaporan ini berisi tentang potensi keuntungan ekonomis yang bisa diperoleh dari bisnis tambang pasir ilegal di Pantai Watu Pecak, Kecamatan Pasirian, Kabupaten Lumajang, Jawa Timur. Seperti diberitakan banyak media, seorang petani yang sekaligus aktivis lingkungan, Salim Kancil, dibunuh karena konflik tambang pasir besi di Desa Selok Awar-awar, Lumajang, Jawa Timur, pada 2 Oktober 2015. Sebelum dibunuh, Salim dikenal aktif menolak tambang ilegal yang diduga menghasilkan omset hingga Rp2 Miliar perbulan.

Berita tentang pembunuhan Salim Kancil dan penganiayaan terhadap rekannya, Tosan, kemudian menghiasi halaman depan surat kabar, media dalam jaringan, serta media penyiaran baik radio maupun televisi. Dalam berbagai sudut pandang media menghadirkannya menjadi berita berkelanjutan. Salah satunya ditampilkan oleh Koran Tempo seperti yang dilihat pada Gambar 3.

\footnotetext{
2 Suprayogi, Yosep, 2015, Menemukan Kisah Sains, materi Konferensi Jurnalis Sains Indonesia
} (Indonesian Science Journalists Conference) di Litbang KLHK, Bogor, Jawa Barat, 29-30 Agustus 2015. 


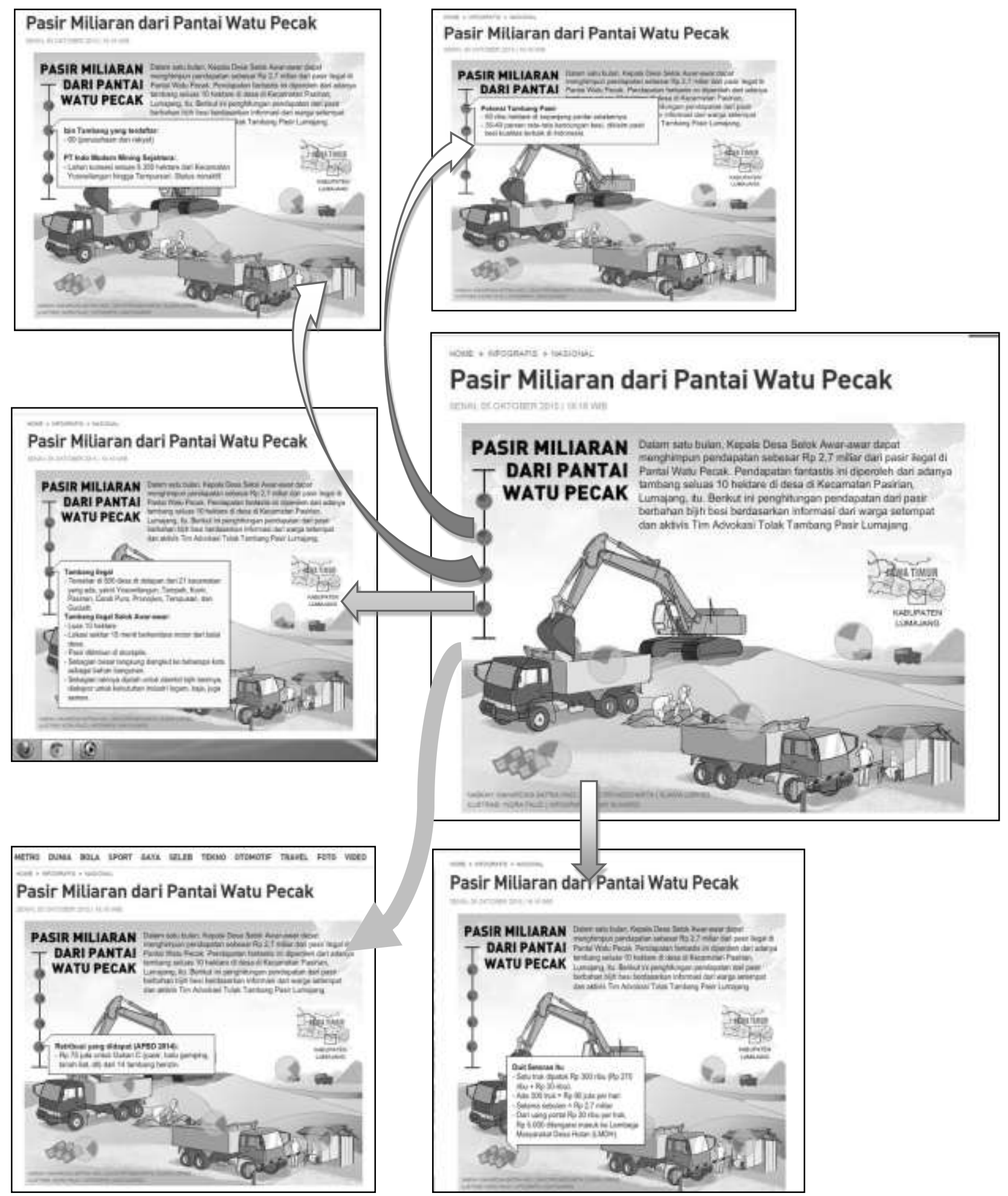

Gambar 3.

Kasus Pengerukan Pasir di Pantai Watu Pecak

Diolah dari : Koran Tempo, Senin 25 Oktober 2015 
Dalam Gambar 3 ini dapat dilihat bahwa Koran Tempo menggunakan pendekatan sains yang meskipun sederhana tapi cukup mampu menjelaskan kepada khalayak tentang "sumber uang" yang menjadi akar persoalan sehingga terjadinya peristiwa ini. Koran Tempo mencoba membeberkan unsur "apa, siapa, di mana, kapan, mengapa, dan bagaimana" dengan menitikberatkan pada unsur "apa" dan "bagaimana". Namun laporan ini juga membawa pesan tentang potensi bencana yang dapat timbul dari pengerukan pasir di tambang seluas 10 hektar itu.

\section{Jurnalisme Sains Sebagai Sistem Pencegahan Dini}

Potensi bencana masih mengintai sejumlah daerah di Indonesia seperti yang dijelaskan di atas menuntut Indonesia untuk memiliki sistem pencegahan dini (early warning system) yang menyeluruh. Kenyataannya, pada sejumlah peristiwa bencana, pemerintah baru melakukan penanganan setelah bencana terjadi. Pada peristiwa bencana lainnya, penanganan dilakukan hanya dengan menggunakan pendekatan “proyek pengadaan alat", misalnya pada peristiwa bencana gempa yang disusul dengan adanya tsunami, pemerintah memilih untuk memberikan bantuan berupa alat pendeteksi gempa dan atau tsunami. Hal ini tentu saja tidak salah. Namun, mempertimbangkan potensi bencana yang begitu besar di Indonesia, pemberian alat sebagai satu-satunya bagian dari sistem pencegahan dini tentu tidak cukup. Apalagi jika pemberian alat ini tidak disertai dengan digugahnya kesadaran dari semua pihak untuk sama-sama memelihara alat pendeteksi bencana itu sehingga dapat berfungsi dengan baik.

Sebagai contoh, pasca kejadian gempa di Mentawai, Sumatera Barat yang terjadi Rabu, 2 Maret 2016, banyak media yang memberitakan bahwa alat pendeteksi gempa di wilayah itu ditemukan rusak dan tidak berfungsi. Hal ini diperparah saat Kepala BNPB, Willem Rampangilei, baru akan melakukan pengecekan terhadap alat deteksi dini gempa setelah mendapatkan laporan bahwa early warning system di Mentawai tidak berfungsi dengan baik (Republika Online, 2016).

Ini bukan yang pertama dan satu-satunya, karena ketidaksiapan ini hampir selalu terjadi di Indonesia dan terlihat jelas tidak ada persiapan secara serius dan berkelanjutan. Tahun demi tahun negeri ini seperti tak lepas dari bencana. Namun, selekas gempa datang, selekas itu pula orang lupa. Tak berubah cara berpikir warga maupun pengelola pemerintah. Proses mitigasi bencana masih tersengal-sengal, tak mampu mengikuti ritme bencana yang menyebar dengan pesat seperti gatal-gatal. Berbeda dengan warga Jepang yang sangat sadar akan ancaman gempa dan tsunami, warga Indonesia belum juga beranjak menyiapkan diri menghadapi ancaman bencana baru (Arif, 2010:22)

Menurut Kepala Pusat Data dan Hubungan Masyarakat BNPB, akibat banyak warga di Banjarnegara, Jawa Tengah yang menganggap alat peringatan dini bencana tak membantu, maka alat itu menjadi berubah fungsi, mulai dari yang roboh, menjadi tempat jemuran, hingga digunakan sebagai tempat mengikat hewan ternak (lihat Gambar 4). Padahal di tempat ini berulang kali terjadi bencana longsor. Hal ini bisa 
terjadi karena pemasangan sistem peringatan dini bencana tidak diimbangi dengan kesadaran warga akan pentingnya mengurangi risiko bencana.

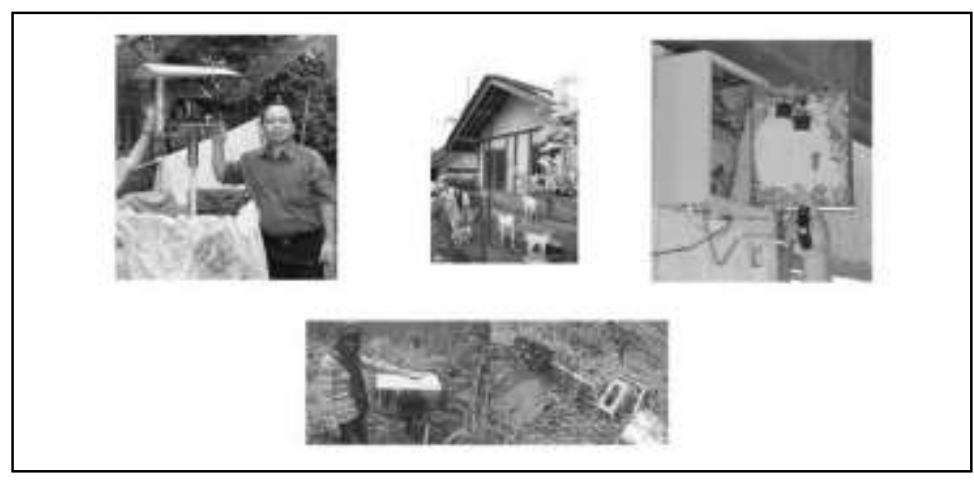

Gambar 4.

Alat Pendeteksi Bencana Berubah Fungsi

Sumber: nationalgeographic.co.id

Roskusumah, dalam penelitiannya tentang komunikasi mitigasi bencana oleh Badan Geologi KESDM di Gunung Api Merapi Prov. D. I. Yogyakarta (2013:59-68), menjelaskan bahwa sudah ada upaya dari pemerintah - dalam hal ini Badan Geologi, dalam membangun kesadaran masyarakat yang bertempat tinggal di wilayah rawan bencana untuk mengantisipasinya melalui komunikasi mitigasi bencana. Caranya dengan menyampaikan informasi awal masalah tentang kebencanaan mulai dari sosialisasi langsung, melalui media, baik itu cetak maupun elektronik maupun simulasi-simulasi teknis kebencanaan.

Namun, komunikasi mitigasi bencana ini kiranya masih punya kelemahan antara lain karena: 1) poin utama dari komunikasi mitigasi bencana adalah mengungsi ketika bencana sudah terjadi dan; 2) masih banyak kendala yang ditemui di lapangan. Kendala internal dari Badan Geologi adalah skala prioritas yang dikedepankan oleh kebijakan internal yang dikeluarkan pimpinan dengan mendahulukan masalah teknis kegeologian. Sedangkan kendala eksternal antara lain berupa kendala bahasa, kendala pendidikan, kesadaran pribadi masyarakat untuk lebih peduli akan lingkungan tempat dia tinggal maupun adanya tantangan kepercayaan lokal yang dimiliki masyarakat, pertumbuhan penduduk yang cepat, pengalaman letusan yang tidak merata dan respon masyarakat terhadap informasi, penyuluhan dan pelatihan yang diadakan pemerintah.

Pada kondisi seperti ini tidak berlebihan kiranya jika kehadiran jurnalisme yang disajikan dengan pendekatan ilmiah dapat mengambil peran yang sangat penting dalam mendukung sistem pencegahan dini (early warning system) yang setiap orang dapat memahaminya dengan mudah.

Dalam materi pelajaran online untuk jurnalisme sains yang dikeluarkan oleh World Federation of Science Journalists, disebutkan bahwa menjelaskan sains itu penting, namun itu bukanlah satu-satunya tugas seorang jurnalis. Para jurnalis harus memopulerkan sains agar dapat memikat minat khalayaknya. Namun jurnalisme sains 
juga (bisa) tentang paparan kepada masyarakat di mana batas pengetahuan kita. Ini berkaitan dengan riset jurnalisme yang baik. Juga tentang menghubungkan sains dengan bagian masyarakat yang lain dan menempatkannya ke dalam perspektif yang lebih luas misalnya politik, ekonomi, kesehatan. Selain itu, jurnalisme sains juga (bisa berupa) kritik kepada ilmuwan dan pakar-pakar lain jika diperlukan.

Keberadaan jurnalisme sains ini tidak terlepas dari konteks komunikasi ilmu. Jenna Jadin Ph.D., seorang penasihat perubahan iklim (climate change advisor) dari USAID/Indonesia membagi komunikasi ilmu sebagai:

1. Komunikasi di antara para ilmuwan.

2. Komunikasi di antara para ilmuwan ini umum ditemukan dalam bentuk pertemuan ilmiah, karya tulis, makalah, seminar atau konferensi. Dalam bentuk ini, komunikasi berlangsung antara pembawa pesan dan penerima pesan yang setara, dengan bahasa yang relatif sama.

3. Komunikasi dari ilmuwan kepada orang awam.

4. Dalam bentuk komunikasi ini, sains dapat dijelaskan kepada siapa saja yang menjadi bagian dari masyarakat seperti pegawai pemerintahan, anak-anak sekolah, mitra di sektor privat, jurnalis, khalayak luas, hingga ibu rumah tangga. Komunikasi yang dibangun dalam bentuk ini diharapkan dapat memberikan pemahaman luas (Jadin, 2016:5).

Pada komunikasi antara ilmuwan, bencana dapat diteliti, didiskusikan, diperdebatkan, dipresentasikan dalam ruang-ruang tertutup yang sangat ilmiah. Hasilnya bisa sangat penting tapi seringkali hanya berakhir menjadi tumpukan di perpustakaan atau di ruang perkuliahan. Sistem pencegahan dini bencana juga kerap menjadi bahan penelitian tapi aplikasinya sulit dilakukan jika masih menggunakan bahasa ilmiah yang asing di telinga orang kebanyakan. Sedangkan pada bentuknya yang kedua, sains dapat dijelaskan kepada siapa saja yang menjadi bagian dari masyarakat. Sistem pencegahan dini bencana tidak lagi menjadi sesuatu yang asing jika pendekatan ilmiah dapat disampaikan dengan bahasa yang "biasa-biasa", yang lebih populer, yang mudah dicerna oleh masyarakat di tempat-tempat langganan bencana. Bantuan pemerintah berupa alat deteksi bencana dengan demikian tidak hanya berhenti pada proses "pengajuan dan pencairan" tapi lebih dari itu ada upaya sosialisasi secara terus menerus, simulasi, hingga pengawasan kepada masyarakat sehingga mereka tidak akan lagi mengabaikan pentingnya peralatan itu tapi juga akan lebih siap menghadapi bencana.

Australian Science Communication and Research Network (Jaringan Penelitian dan Komunikasi Sains Australia) mencatat komunikasi sains yang efektif memberi masyarakat informasi akurat yang dapat dijadikan dasar dalam mengambil keputusan. Dengan menjadikan sains mudah diakses, komunikator sains membantu menangkal misinformasi dan miskonsepssi yang mengacaukan perdebatan publik (Jadin, 2016:7). Pendapat ini semakin menguatkan asumsi bahwa komunikasi sains tentang bencana dan sistem pencegahannya jika disampaikan dengan efektif akan mempermudah masyarakat dalam menghadapi bencana itu. Dalam hal inilah 
jurnalisme sebagaimana tugasnya menyampaikan informasi dan komunikasi kepada khalayak mengambil peran yang besar.

Pada saat menyampaikan komunikasi ilmu ini ada beberapa kaidah yang dapat digunakan. Pertama, memahami khalayak. Penting memahami khalayak agar penyampaian informasi dapat tepat sasaran. Latar pendidikan khalayak, misalnya, akan cukup menentukan apakah sistem pencegahan dini bencana dapat dipahami. Apa yang mereka ketahui tentang alat pendeteksi bencana, bagaimana alat itu beroperasi, bagaimana mereka bersahabat dengan alam sehingga saat bencana datang, mereka sudah mengantisipasinya, dan sebagainya.

Kedua, fokus pada nilai-nilai kemanusiaan. Bencana yang besar dan siap datang sewaktu-waktu di Indonesia sudah cukup menjadi alasan bagi media menghadirkan informasi dengan metode ilmiah. Mungkin terlalu naif jika menginginkan tidak ada satu pun korban dari bencana ini, tapi meminimalisasi jumlahnya saya kira merupakan alasan kemanusiaan yang paling hakiki.

Ketiga, jelas dan sederhana. Menurut Kovach dan Rosenthiel dalam "9 Elements of Journalism" (2001:67), salah satu elemen jurnalisme adalah berusaha membuat yang penting menjadi menarik dan relevan. Oleh karena itu, bahasa ilmiah yang ditulis oleh para ilmuwan harus disampaikan dengan lebih menarik dan relevan oleh jurnalis. Istilah-istilah akademis dan ilmiah yang rumit bisa diterjemahkan jurnalis sehingga masyarakat dapat membacanya di media dengan mudah.

Keempat, menyediakan solusi. Sebagian ahli dan praktisi jurnalisme masih percaya bahwa media massa (pers) harus tetap menjaga netralitasnya. Hal ini selalu dihubungkan dengan konsep obyektivitas media, salah satunya menghindari keberpihakan. Namun dalam konteks jurnalisme sains ini, menyediakan solusi sudah tidak relevan lagi dengan ketidakberpihakan. Karena jurnalisme dinilai sudah harus beranjak dari fakta ke makna. Maka menawarkan solusi untuk menyelesaikan persoalan bencana merupakan salah satu kaidah yang dipegang oleh jurnalis dan media tempatnya bekerja.

Kelima, selalu siap. Jurnalis sains selalu menyediakan waktu mencari dan mempelajari masalah yang akan ditulisnya. Dalam mendukung sistem pencegahan dini bencana, dia dapat memetakan sejumlah hal seperti:

- Merumuskan masalah - bagaimana caranya menjelaskan secara sederhana pencegahan bencana ini dan apa artinya bagi pembaca, pendengar, pemirsa

- Melakukan riset - mencari isu terdahulu yang relevan dengan pencegahan bencana ini

- Membuat sesuatu yang nyata - bagaimana media dapat menarik perasaan, tidak hanya pikiran

- Membuat purwarupa dan tes - bagaimana alat deteksi bencana bekerja atau bagaimana reaksi warga jika terjadi bencana. Jurnalis tidak melahap pernyataan ilmuwan tanpa mengetahui pembuktian cara kerja alatnya.

- Berkolaborasi - bekerjasama dengan orang-orang apakah itu ilmuwan atau praktisi, yang menguasai persoalan bencana ini dari lintas disiplin keilmuan. 
Keenam, mencakup percobaan. Ilmu pengetahuan serta teknologi yang senantiasa berkembang menuntut adanya perubahan, tidak terkecuali jurnalisme. Salah satu perubahan yang begitu terasa adalah derasnya informasi dan berita yang setiap hari masuk ke ruang aktivitas sehari-hari, baik berita yang diproduksi oleh media mainstream maupun oleh warga (citizen journalist). Gilmor (2006:xxiv) menyebutkan, saat ini ada tiga "konstituen" di dunia ini di mana setiap orang dapat membuat berita. Meski di antara ketiganya sangat berbeda, namun seringkali mereka "saling menyamarkan" satu sama lain. Mereka adalah: 1) Jurnalis, yaitu kelompok yang menjadi bagian dari sesuatu yang baru di mana pembaca/pendengar/atau audiens menjadi bagian dari proses ini; 2) newsmaker; dan 3) khalayak terdepan.

Maka peran jurnalisme sains adalah senantiasa menyediakan ruang masuknya informasi dengan melibatkan "konstituen" ini untuk melakukan eksperimen. Dengan demikian pelaporan yang dihasilkan oleh jurnalisme sains ini akan lebih lengkap, cepat, dan lebih personal. Warga akan lebih perduli dalam mengantisipasi bencana jika secara bersama-sama juga diberi kesempatan untuk membangun sisitem pencegahan dini bencana itu.

Kaidah-kaidah ini juga dapat lebih menegaskan bahwa jurnalisme sains dapat menjadi alat untuk membantu memudahkan penyampai pesan (komunikator) dalam menyampaikan pesannya kepada penerima pesan atau audiensnya.

\section{Simpulan}

Berdasarkan paparan yang telah disajikan di atas maka dapat ditarik simpulan bahwa pemerintah melalui BNPB mencatat betapa sudah banyak kerugian yang harus ditanggung bangsa ini akibat bencana, baik bencana alam maupun bencana yang diakibatkan oleh tingkah polah manusianya. Kerugian akan terus bertambah jika pemerintah dan masyarakat tidak meningkatkan kepedulian dan keseriusan dalam mengantisipasi datangnya bencana. Untuk itu, meneguhkan perannya melalui media massa, jurnalisme dapat mengambil peran penting dalam mendukung sistem peringatan dini bencana di Indonesia, yaitu dengan menerapkan metode jurnalisme sains cara untuk menjembatani para ilmuwan yang melakukan kajian ilmiah, dengan publik, terutama warga yang tinggal di daerah rawan bencana. Peran yang paling nyata dapat dilakukan dengan menyajikan pelaporan ilmiah yang diramu dengan bahasa populer. Pelaporan ini dapat mendukung sistem peringatan dini (early warning system), suatu hal penting yang selama ini sering diabaikan baik oleh pemerintah sebagai institusi yang paling bertanggung jawab terhadap keamanan dan kenyamanan warga negaranya maupun oleh masyarakat sendiri.

\section{Daftar Pustaka}

Arif, Ahmad. 2010, Jurnalisme Bencana, Bencana Jurnalisme: Kesaksian dari Tanah Bencana. Jakarta: KPG (Kepustakaan Populer Gramedia).

Gilmor, Dan. 2006. We the Media: Grassroots Journalism by The People, for The People. Sebastopol: O’Reilly Media Inc. 
http://nasional.kompas.com/read/2015/11/13/14001291/BNPB.Diberi.Alokasi.Rp.15 0.Miliar.untuk.Tangani.Banjir.dan.Tanah.Longsor diunduh pada hari Jumat (13 November 2015) pukul 17.44 WIB).

http://www.republika.co.id/berita/koran/podium/15/12/30/o05vk713-bersiapmenghadapi-bencana, diunduh pada hari Jumat (22 Februari 2016) pukul 21.44 WIB.

http://www.republika.co.id/berita/nasional/daerah/16/03/04/o3i46i365-bnpb-segeraperbaiki-alat-deteksi-gempa-yang-rusak, diunduh pada hari Jumat, 4 Maret 2016, pukul 18:18 WIB.

http://ugm.ac.id/id/berita/3557-jauh.sebelum.2004.aceh.pernah.alami.giant.tsunami, diunduh pada hari Jumat (13 November 2015) pukul 18.04 WIB.

Harian Kompas Kamis, 29 Oktober 2015

Harrower, Tim. 2010. Inside Reporting: A Practical Guide to the Craft of Journalism. New York: McGraw-Hill.

Indiyanto, Agus \& Arqom Kuswanjono (Ed). 2012. Respons Masyarakat Lokal Atas Bencana, Kajian Integratif Ilmu, Agama, dan Budaya. Bandung dan Yogyakarta: kerjasama PT. Mizan Pustaka dengan Program Studi Agama dan Lintas Budaya (Center for Religious \& Cross-cultural Studies).

Jadin, Jenna. 2015. Making Your Science Matter. Materi Konferensi Jurnalis Sains Indonesia (Indonesian Science Journalists Conference) di Litbang KLHK, Bogor, Jawa Barat, 29-30 Agustus 2015.

Julianto, Irwan. 2002. Jika Ia Anak Kita, AIDS dan Jurnalisme Empati. Jakarta: Penerbit Buku Kompas.

Jurnalisme Sains, Ketika Jurnalis Menjadi Ilmuwan. http://degorontalo.co/jurnalisme-sains-ketika-jurnalis-menjadi-ilmuwan/Koran Tempo, Senin 25 Oktober 2015.

Kovach, Bill and Tom Rosentiel. 2001. The Elements of Journalism. New York: Crown Publishers.

Kusumaningrat, Hikmat, dan Purnama Kusumaningrat. 2005. Jurnalistik Teori \& Praktik. Bandung: PT. Remaja Rosdakarya. (Referensi belum muncul eksplisit di badan tulisannya)

Majalah TEMPO. Edisi Kilas Balik 2015. Tokoh Tempo 2015, Para Penakluk Asap. 28 Desember 2015-3 Januari 2016.

Reh [Stevenson], Emma. siarchives.si.edu/research/sciservwomenreh.html, diakses pada 5 Maret 2015, pukul 11.30 WIB.

Roskusumah, Titan. Komunikasi Mitigasi Bencana oleh Badan Geologi KESDM di Gunung Api Merapi Prov. D. I. Yogyakarta. Jurnal Kajian Komunikasi, Volume 1, Nomor 1, Juni 2013, hlm 59-68.

Schechter, Danny. 2007. Matinya Media - Perjuangan Menyelamatkan Demokrasi (terjemahan dari The Death of Media and The Fight to Save Democracy). Jakarta: Yayasan Obor Indonesia. 
Rana Akbari Fitirawan: Jurnalisme Sains dan Sistem Peringatan Dini Bencana di Indonesia ... $\mid 57$

Siregar, Ashadi. Media Pers dan Negara Keluar dari Hegemoni. Jurnal Ilmu Sosial dan Ilmu Politik Volume 4, Nomor 2, Nopember 2000 (171-196).

Siregar, Ashadi. Krisis Dua Profesi. Harian Kompas 11 Agustus 2015. 